\title{
PERSEPSI MASYARAKAT DAN KEPEMIMPINAN PEREMPUAN
}

\author{
AMTAI ALASLAN, S.IP.,M.Si \\ (Dosen STIA Saumlaki)
}

\begin{abstract}
ABSTRAK
Penilitian ini dilakukan untuk mengetahui pengaruh antara Persepsi Masyarakat terhadap Kepemimpinan Perempuan Di Desa Lauran Kecamatan Tanimbar Selatan Kabupaten Maluku Tenggara Barat. Pengumpulan data dilakukan dengan menggunkan kuesioner sebagai instrumen utama penelitian dengan sampel sebanyak 95 responden yang analisa dengan munggunakan rumus Korelasi Pearson Pruduck Moment dan uji signifikasinya digunakan rumus t-hitung

Hasil penelitian menjukan bahwa variabel X (Persepsi Masyarakat) mempunyai hubungan yang cukup kuat dengan variabel Y (Kepemimpinan Perempuan). Hal ini juga diperkuat dengan data yang diperoleh dengan persamaan koefisien determinasi dimana variabel bebas memberikan kontribusi sebesar $25 \%$ terhadap variabel terikat sedangkan sisanya $75 \%$ ditentukan oleh faktorfaktor lain.

Uji signifikansi dengan menggunkan uji t (t-hitung), derajat kepekaan 5\% uji dua pihak dengan $\mathrm{dk}=95-2=93$ diperoleh nilai t-hitung lebih besar dari nilai t- tabel $(5,542>1,980)$, maka $\mathrm{H}_{\mathrm{a}}$ diterima dan $\mathrm{H}_{0}$ ditolak artinya ada pengaruh antara Persepsi Masyarakat terhadap Kepemimpinan Perempuan Di Desa Lauran Kecamatan Tanimbar Selatan Kabupaten Maluku Tenggara Barat.
\end{abstract}

Kata kunci : Persepsi Masyarakat dan Kepemimpinan Perempuan.

\begin{abstract}
This research was conducted to determine the influence between the Public Perception of Women's Leadership in Lauran Village, South Tanimbar Subdistrict, Southeast Maluku Regency. Data collection was done by using questionnaires as the main instrument of the study with a sample of 95 respondents who analyzed by using Pearson Pruduck Moment Correlation formula and the significance test used t-test formula

The results showed that the variable $X$ (Perception Society) has a strong enough relationship with variable Y (Leadership of Women). This is also reinforced by the data obtained by the coefficient of determination where independent variables contribute $25 \%$ to the dependent variable while the remaining $75 \%$ is determined by other factors.

Test of significance by using t test (t-hitung), degree of sensitivity $5 \%$ test two parties with dk = $95-2=93$ obtained t-count value greater than t-table value $(5,542>1,980)$, Ha accepted and H0 rejected means there is influence between the Public Perception of Women's Leadership in Lauran Village, South Tanimbar District, West Southeast Maluku Regency.
\end{abstract}

Keywords: Community Perceptions and Women's Leadership. 
PENDAH LUAN

Keberhasilan suatu organisasi sangat tergantung dengan peranan seorang pemimpin karena karena pemimpin merupakan penggerak utama di dalam mewujudkan kesuksesan organisasi. Dalam mencapai kesuksesan, seorang pemimpin memerlukan bantuan dari pihak bawahan agar tercipta kerjasama yang baik di dalam menjawab tujuan, tuntutan serta tantangan yang dihadapi oleh oraganisasi.

Kepemimpinan (leadership) dapat dikatakan sebagai cara dari seorang pemimpin (leader) dalam mengarahkan, mendorong dan mengatur seluruh unsurunsur di dalam kelompok atau organisasinya untuk mencapai suatu tujuan organisasi yang diinginkan. Pemimpin harus mengenal dan mengetahui orang-orang yang ia pimpin dalam suatu organisasi. Pemimpin juga bertanggungjawab akan semua hal yang menyangkut organisasi yang ia jalankan. Oleh karena itu, kemampuan dan keterampilan dalam memimpin merupakan faktor penting dalam efektifitas organisasi.

Bila organisasi dapat mengidentifikasi kualitas-kualitas yang berhubungan dengan kepemimpinan, kemampuan untuk menyeleksi pemimpin - pemimpin yang aktif akan meningkat, bila organisasi dapat mengidentifikasikan perilaku dan teknik - teknik kepemimpinan efektif organisasi, berbagai perilaku dan teknik tersebut akan dapat dipelajari, karena merupakan salah satu faktor yang dapat membentuk dan mambantu orang lain untuk bekerja dalam mencapai tujuan yang direncakan.

Kepemimpinan adalah hubungan antar manusia, yaitu hubungan memengaruhi dan hubungan kepatuhanketaatan para pengikut atau bawahan karena dipengaruhi oleh kewibawaan pemimpin, Dalam ranah kepemimpinan ada tiga hal yang harus dikembangkan oleh seorang pemimpin yakni seorang pemimpin harus mampu memimpin diri sendiri (managing self), memimpin orang (mananging people), dan memimpin tugas (mananging job). Efektivitas dalam melaksanakan kepemimpinan harus dimulai dari diri sendiri. Tidak mungkin seorang pemimpin yang gagal membuat dirinya efektif akan berhasil dalam mengefektifkan orang lain ataupun pekerjaannya (Kartono, 2013:2).

Dari gambaran di atas terlihat dengan jelas bahwa kemajuan dan kemunduran suatu organisasi tergantung dari kualitas kepemimpinan seorang pemimpin. Dilihat dari sudut pandang apapun juga pemimpin selalu ditempatkan pada satu titik yang sangat penting. Peran seorang pemimpin dalam 
satu organisasi atau kelompok sangatlah vital baik itu laki-laki maupun perempuan.

Manusia sebagai makluk sosial memiliki keinginan, komitmen dan tanggungjawab untuk menjadi seorang pemimpin, baik itu pada jenjang pendidikan maupun pada birokrasi pemerintahan, hal ini menunjukan bahwa kaum perempuan juga dapat ikut berpartisipasi dalam mengisi pembangunan daerah. Perempuan senantiasa ditempatkan sebagai kaum lemah yang dikodrati untuk harus tunduk dan taat pada laki-laki, sebab pekerjaan yang berat selalu dikerjakan oleh laki-laki dari pada perempuan. Hal ini menjadi tidak sebanding dengan kondisi sekarang bahwa perempuan telah mendapat porsi yang istimewah bahwa perempuan sebagai pekerja yang membawa inspirasi dan kesejukan dalam pekerjaan bahkan kenyamanan pekerjaan menjadi menyenangkan.

Menurut Supartiningsih (2003), data statistik seluruh dunia selalu menunjukan bahwa angka partisipasi perempuan dalam pasar kerja dan politik selalu lebih kecil dari laki-laki, sementara Astuti (2011 :16) menerangkan bahwa faktor utama yang menghambat kesempatan perempuan untuk terjun dalam dunia politik yaitu pandangan stereotip bahwa dunia politik adalah dunia yang keras, memerlukan akal, dunia yang penuh debat, dan membutuhkan pikiran- pikiran cerdas, yang kesemuanya diasumsikan milik laki-laki bukan milik perempuan. Perempuan tidak pantas berpolitik karena perempuan adalah penghuni dapur, tidak bisa berpikir rasional dan kurang berani mengambil resiko, memiliki tingkat keraguan yang cukup tinggi, takut terhadap fenomena masyarakat, memiliki tingkat pendidikan yang terbatas dan kurang memiliki akses di masyarakat untuk menyampaikan pendapat dalam proses pengambilan keputusan.

Dengan kondisi demikian, hanya sedikit perempuan yang terlibat dalam dunia politik, sehingga sebagian besar perempuan berada dalam sektor domestic. Walaupun perempuan memiliki hak dan kewajiban yang sama dalam dunia politik namun partisipasi perempuan untuk terlibat dalam dunia politik masih rendah, salah satunya adalah di Kabupaten Maluku Tenggara Barat dimana derajat seorang perempuan sangat diutamakan, akan tetapi dalam pemerintahan desa perempuan tidak atau bahkan jarang dilibatkan dalam pengambilan keputusan terutama saat upacara adat istiadat dalam sebuah desa.

Dengan berbagai hambatan bagi perempuan untuk terjun dalam dunia publik, namun ditemukan bahwa ada 
perempuan yang bisa menjadi pemimpin, salah satunya adalah sebagai Kepala Desa. Hal ini seperti yang ditemui di Desa Lauran Kecamatan Tanimbar Selatan Kabupaten Maluku Tenggara Barat, dimana kepala desa yang memimpin saat ini adalah seorang perempuan dari 10 Kepala Desa yang ada di Kecamatan Tanimbar Selatan dan menjadi pusat perhatian masyarakat dalam perkembangannya kedepan sehingga perlu diketahui persepsi masyarakat terhadap kepemimpinan perempuan di Desa Lauran Kecamatan Tanimbar Selatan Kabupaten Maluku Tenggara Barat.

\section{LANDASAN TEORI}

\section{Pengertian Persepsi}

Kata "Persepsi" seringkali digunakan dalam kehidupan sehari-hari, yang merujuk pada proses pemberian arti atau makna terhadap informasi, peristiwa, objek dan lainnya yang berasal dari lingkungan sekitar oleh individu atau masyarakat dalam kehidupan sehari-hari.

Menurut Kamus Besar Bahasa Indonesia, Purwodarminto (1990:759), "persepsi adalah tanggapan langsung dari suatu serapan atau proses seseorang mengetahui beberapa hal melalui pengindraan". Sementara menurut Sugihartono (2007:8), persepsi adalah kemampuan otak dalam menerjemahkan stimulus atau proses untuk menerjemahkan stimulus yang masuk ke dalam alat indera manusia.

Istilah persepsi sering disebut juga dengan pandangan atau anggapan, sebab dalam persepsi terdapat tanggapan seseorang mengenai suatu hal atau objek. Persepsi mempunyai banyak pengertian. Secara umum persepsi adalah proses mengamati dunia luar yang mencakup perhatian, pemahaman dan pengenalan objek- objek atau peristiwa. Biasanya persepsi diorganisasikan ke dalam bentuk (figure), dasar (ground), garis bentuk (garis luar, kontur)dan kejelasan (Pieter dan \& Lubis, 2010:49).

Dengan pemaknaan Persepsi manusia tersebut maka ada perbedaan sudut pandang dalam penginderaan, ada yang mempersepsikan sesuatu itu baik atau persepsi yang positif maupun persepsi negatif akan memengaruhi tindakan manusia yang tampak atau nyata.

\section{Proses Pembentukan Persepsi}

Menurut Toha (2003:145), proses terbentuknya persepsi didasari pada beberapa tahapan, yaitu :

a. Stimulus atau rangsangan, Terjadinya persepsi diawali ketika seseorang dihadapkan pada suatu stimulus/rangsangan yang hadir dari lingkungannya;

b. Registrasi dalam proses registrasi, 
suatu gejala yang nampak adalah mekanisme fisik yang berupa penginderaan dan syarat seseorang berpengaruh melalui alat indera yang dimilikinya. Seseorang dapat mendengarkan atau melihat informasi yang terkirim kepadanya, kemudian mendaftar semua informasi yang terkirim kepadanya tersebut;

c. Interpretasi merupakan suatu aspek kognitif dari persepsi yang sangat penting yaitu proses memberikan arti kepada stimulus yang diterimanya. Proses interpretasi tersebut bergantung pada cara pendalaman, motivasi, dan kepribadian seseorang.

Apabila ditinjau dari segi timbulnya perhatian, dapat dibedakan menjadi dua, yaitu :

a. Perhatian spontan perhatian spontan adalah perhatian yang timbul dengan sendirinya, timbul secara spontan. Perhatian ini erat hubunganya dengan minat individu, bila individu telah memiliki minat terhadap objek, maka terhadap objek biasanya timbul perhatian yang spontan, secara otomatis perhatian itu akan timbul;

b. Perhatian tidak spontan perhatian tidak spontan adalah perhatian yang ditimbulkan dengan sengaja, karena itu harus ada kemauan untuk menimbulkannya.

Persepsi dapat dikatakan sebagai suatu proses penginderaan, stimulus yang diterima oleh individu melalui alat indera yang kemudian diinterpretasikan sehingga individu dapat memberikan pandangan, memahami dan dapat mengartikan tentang stimulus yang diterimanya. Proses menginterpretasikan ini biasanya dipengaruhi oleh pengalaman dan proses belajar individu. Persepsi yang dimaksud dalam penelitian ini adalah persepsi masyarkat terhadap kepemimpinan kepala desa perempuan di Desa Lauran Kecamatan Tanimbar Selatan.

\section{Pengertian Masyarakat}

Kata masyarakat berasal dari musyarak (arab),yang artinya bersamasama, kemudian berubah menjadi masyarakat, yang artinya berkumpul bersama, hidup bersama saling berhubungan dan saling mempengaruhi, selanjutnya mendapatkan kesepakatan menjadi masyarakat (Indonesia). Menurut Auguste Comte dalam Abdul Syani (2007:31), "Masyarakat adalah kelompok-kelompok makhluk hidup dengan realitas baru yang berkembang menurut hukum-hukumnya sendiri dan berkembang menurut pola perkembangan tersendiri” dengan ciri : Mempunyai 
wilayah dan batas yang jelas, Merupakan suatu kesatuan penduduk, Terdiri atas kelompok-kelompok fungsional yang heterogen, Mengemban fungsi umum, Memiliki kebudayaan yang sama (dalam Handoyo, 2007:1)

Berdasarkan pernyataan tersebut di atas dapat disimpulkan bahwa ciri-ciri dan syarat masyarakat adalah, masyarakat bukan hanya sekumpulan manusia yang hidup untuk kepentingan diri sendiri, namun memiliki kepentingan dan tujan yang sama yang diatur berdasarkan peraturan yang telah ditetapkan.

\section{Pengertian Persepsi Masyarakat}

Menurut kamus bahasa Inggris, masyarakat disebut society asal katanya socius yang berarti kawan. Arti yang lebih khusus, bahwa masyarakat adalah kesatuan sosial yang mempunyai kehidupan jiwa seperti adanya ungkapanungkapan jiwa rakyat, kehendak rakyat, kesadaran masyarakat dan sebagainya. Sedangkan jiwa masyarakat ini merupakan potensi yang berasal dari unsur-unsur masyarakat meliputi pranata, status dan peranan sosial. Sehingga pengertian masyarakat adalah "kumpulan individu-individu yang saling bergaul berinteraksi karena mempunyai nilai-nilai, norma-norma, cara-cara dan prosedur yang merupakan kebutuhan bersama berupa suatu sistem adat istiadat tertentu yang bersifat kontinue dan terikat oleh suatu identitas bersama" (Musadun, 2000 : 40 dalam Adrianto, 2006: 60).

Persepsi masyarakat merupakan tanggapan atau pengetahuan lingkungan dari kumpulan individu- individu yang saling bergaul berinteraksi karena mempunyai nilai- nilai, norma-norma, cara-cara dan prosedur merupakan kebutuhan bersama berupa suatu sistem adat-istiadat yang bersifat kontinue dan terikat oleh suatu identitas bersama yang diperoleh melalui interpretasi data indera. Dengan kata lain persepsi masyarakat dapat didefinisikan sebagai rangkaian proses kognisi atau pengenalan dan afeksi atau aktifitas evaluasi emosional (ketertarikan) masyarakat terhadap suatu objek, peristiwa, atau hubungan-hubungan yang diperoleh dengan cara menyimpulkan informasi dan menafsirkan pesan tersebut dengan menggunakan media pendengaran, penglihatan, peraba dan sebagainya.

\section{Pengertian Kepemimpinan}

Menurut Fairchild dalam Kartono (1994 : 33), Pimpinan dalam pengertian luas ialah seorang yang memimpin, jelas memprakarsai tingkahlaku atau mengontrol usaha atau upaya orang lain atau melalui prestise, kekuasaan atau 
posisi. Selanjutnya dalam Burby (1986:32), mengatakan bahwa : Pimpinan adalah orang yang tindakannya mendorong orang-oranguntuk mengikuti dengan suka rela.

Seorang pimpinan dibutuhkan untuk mengatur, mengarahkan dan membangun hubungan interaksi antara kelompok dengan individu, agar tidak sampai menyimpang dari aturan-aturan dan norma- norma yang telah ditetapkan, oleh karena itu pimpinan dianggap sebagi pelindung, tempat bertanya minta nasehat, sekaligus sebagai pendorong dan pembimbing bagi masyarakat menuju tujuan yang dicita-citakan dengan demikian kepemimpinan senantiasa menjadi pusat dalam kehidupan seharihari.

Dengan demikian kepemimpinan sangat besar pengaruhnya terhadap pencapaian organisasi karena ktivitas dan kinerja anggota pengikut dalam organisasi sebagian besar dipengaruhi oleh adanya pemimpin. Pemimpin adalah seorang pribadi yag memiliki kecakapan atau kelebihan dalam suatu bidang sehingga dia mampu mempengaruhi orang lain untuk sama-sama melakukan aktivitasaktivitas tertentu demi pencapaian tujuan (Kartini, 1999).

\section{Pengertian Perempuan}

Secara etimologis, kata perempuan berasal dari kata empu yang berarti tuan, orang yang mahir/berkuasa, atau pun kepala, hulu, atau yang paling besar; Kata perempuan juga berhubungan dengan kata ampu sokong, memerintah, penyangga, penjaga keselamatan, bahkan wali; kata mengampu artinya menahan agar tidak jatuh atau menyokong agar tidak runtuh; kata mengampukan berarti memerintah (negeri); ada lagi pengampu yakni penahan, penyangga, penyelamat; Kata perempuan juga berakar erat dari kata empuan; kata ini mengalami pemendekan menjadi puan yang artinya sapaan hormat pada perempuan, sebagai pasangan kata tuan yang merupakan sapaan pada lelaki.

Dalam Nugroho (2008: 2) disebutkan bahwa: "Perempuan merupakan manusia yang memiliki alat reproduksi, seperti rahim, dan saluran untuk melahirkan, mempunyai sel telur, memiliki vagina, dan mempunyai alat untuk menyusui, yang semuanya secara permanen tidak berubah dan mempunyai ketentuan biologis atau sering dikatakan sebagai kodrat (ketentuan Tuhan)." Secara kultural Nugroho, mengatakan "perempuan itu dikenal lemah lembut, cantik, emosional dan keibuan". Dari pemaparan teori-teori di atas maka dapat dikatakan bahwa kata perempuan dapat diartikan sebagai sosok yang tangguh, mandiri, aktif, berperan dan 
berdaya, sehingga penulis menilai kata perempuan pantas disandingkan dengan kata pembangunan yang juga perlu peran aktif dari seluruh masyarakat.

Dengan demikian dapat dijelaskan bahwa kepemimpinan perempuan adalah suatu bentuk keterlibatan perempuan dalam memimpin secara mental dan emosional dalam suatu kelompok yang mendorongnya untuk memberikan sumbangan baik dalam bentuk tenaga, fikiran maupun materiil guna tercapainya suatu tujuan tertentu yang akan dicapai.

\section{METODOLOGI PENELITIAN}

Metode yang digunakan dalam penelitian ini adalah metode penelitian kuantitatif asosiatif yakni jenis penelitian yang digunakan untuk mengetahui hubungan atau pengaruh antara dua variabel atau lebih (Sugiono 2009:11). Dengan locus penelitian pada Desa Lauran Kecamatan Tanimbar Selatan Kabupaten Maluku Tenggara Barat.

Penerikan sampel dilakukan dengan teknik purposive jumlah responden sebanyak 95 orang yang diukur dengan mengunakan rumus Slovin pada populasi penelitian Masyarakat Desa Lauran Kecamatan Tanimbar Selatan Kabupaten Maluku Tenggara Barat yang berjumlah 1.909. Data dikumpulakan dengan menggunakan kusioner, observasi, wawancara dengan kepustakaan.
Data yang berhasil dikumpulkan dalam penelitian ini akan dianalisa dengan menggunakan alat analaisa statistik Korelasi Pearson Pruduck Moment yaitu :

$$
\mathrm{r}_{\mathrm{xy}}=\frac{n\left(\sum X Y\right)-\left(\sum X\right) \cdot\left(\sum Y\right)}{\sqrt{\left\{n \sum X^{2}-\left(\sum X\right)^{2}\right\}\left\{\left(n \sum Y^{2}-\left(\sum Y\right)^{2}\right\}\right.}}
$$

Dimana :

$$
\begin{aligned}
& \mathrm{r}=\text { Kepemimpinan Perempuan } \\
& \mathrm{X}=\text { Nilai atau Skor Persepsi }
\end{aligned}
$$

Masyarakat

$$
\mathrm{Y}=\text { Nilai/ Skor Kepemimpinan }
$$

Perempuan

$$
\mathrm{n}=\text { Jumlah Sampel }
$$

Sedangkan arti harga $\mathrm{r}$ akan dikonsultasikan dengan nilai interpretasi pada tabel Koefisien Korelasi sebagai berikut :

\begin{tabular}{|c|l|}
\hline Interval Koefisien & Tingkat Hubungan \\
\hline $0,80-1,000$ & Sangat kuat \\
\hline $0,60-0,799$ & Kuat \\
\hline $0,40-0,599$ & Cukup kuat \\
\hline $0,20-0,399$ & Rendah \\
\hline $0,00-0,199$ & Sangat rendah \\
\hline
\end{tabular}

Selanjutnya untuk menyatakan besar kecilnya sumbangan Varibel X terhadap Variabel Y dapat ditentukan dengan rumus Koefisien Determinan sebagai berikut :

$$
K P=r^{2} \times 100 \%
$$

Untuk menguji kebenaran hipotesa 
penelitian, akan di uji signifikasinya dengan rumus uji t ( $t$-test ) pada taraf nyata $5 \%(0,05)$ uji dua arah dan $\mathrm{dk}=$ n-2 dengan formula sebagai berikut :

$$
t_{\text {hitung }}=\frac{r \sqrt{n-2}}{\sqrt{1-r^{2}}}
$$

Kaidah Pengujian :

Jika Jika thitung $\geq t_{\text {tabel}}$, maka signifikan Jika $t_{\text {hitung }} \leq \mathrm{t}_{\text {tabel }}$, maka tidak signifikan.

\section{PEMBAHASAN}

Hasil penelitian menunjukan bahwa variabel Persepsi Masyarakat berpengaruh signifikan terhadap Kepemimpinan Perempuan di Desa Lauran Kecamatan Tanimbar Selatan Kabupaten Maluku Tenggara Barat yang akan diuraikan sebagai berikut :

\section{Persepsi Masyarakat di Desa Lauran}

Persepsi masyarakat merupakan rangkaian proses kognisi atau pengenalan dan afeksi atau aktifitas evaluasi emosional (ketertarikan) masyarakat terhadap suatu objek, peristiwa, atau hubungan-hubungan yang diperoleh dengan cara menyimpulkan informasi dan menafsirkan pesan tersebut dengan menggunakan media pendengaran, penglihatan, peraba dan sebagainya.

Dari hasil penelitian yang dilakukan menunjukan bahwa variabel Persepsi Masyarakat mempunyai pengaruh yang signifikan terhadap kepemimpinan perempuan. Hal ini ditentukan dengan indikator-indikator pembentuknya yaitu :

1. Perhatian tentang programprogram Desa

2. Pemahaman tentang tugas-tugas Desa

3. Seleksi terhadap aparatur Desa

4. Interpretasi dalam menjalankan tugas Desa

Keempat indikator ini perlu diterapkan dan diberdayakan secara maksimal agar persepsi masyarakt semakin baik terhadap kepemimpinan perempuan di Desa Lauran. Hal ini dapat dilihat dengan data yang dihasilkan sebagai berikut :

1. Untuk pernyataan pertama mengenai perhatian, dari 95 responden ternyata terdapat 3 orang $(3,2 \%)$ menjawab sangat setuju, dan 25 orang $(26,3 \%)$ menjawab setuju, sedangkan 22orang $(23,1 \%)$ menjawab raguragu serta 45 orang $(47,4 \%)$ menjawab tidak setuju.

2. Untuk pernyataan kedua mengenai pemahaman, dari 95 responden ternyata yang menjawab sangat setuju 20 orang $(21,1 \%)$ dan yang menjawab setuju 70 orang $(73,7 \%)$, sedangkan yang menjawab raguragu sebanyak 5 orang $(5,2 \%)$. 
3. Untuk pernyataan ketiga mengenai seleksi, dari 95 responden ternyata yang menjawab sangat setuju sebanyak 17 orang $(17,9 \%)$, yang menjawab setuju sebanyak74 orang $(77,89 \%)$ dan yang menjawab ragu- ragu sebanyak 4 orang $(4,21 \%)$.

4. Untuk pernyataan keempat mengenai interpretasi, dari 95 responden ternyata yang menjawab sangat setuju sebanyak 9 orang $(9,47 \%)$, dan yang menjawab setuju sebanyak 37 orang $(38,95 \%)$ sedangkan yang menjawab ragu-ragu sebanyak 33 orang $(34,74 \%)$ serta yang menjawab tidak setuju sebanyak 16 orang $(16,84 \%)$.

Dari ke empat indicator di atas pada variable bebas diatas yang lebih penting untuk dilakukan yaitu indicator pemahaman. Karena tanpa pemahaman yang baik kepada masyarakat, semua program desa yang telah direncanakan tidak dapat berjalan dengan baik.

\section{Kepemimpinan Perempuan di Desa Lauran}

Kepemimpinan adalah kemampuan mempengaruhi orang lain untuk melaksanakan apa yang perintahkan dalam proses pencapaian tujuan yang diinginkan, atau dengan kata lain Kepemimpinan (leadership) dapat dikatakan sebagai cara dari seorang pemimpin (leader) dalam mengarahkan, mendorong dan mengatur seluruh unsurunsur di dalam kelompok atau organisasinya untuk mencapai suatu tujuan organisasi yang diinginkan.

Sementara itu, Kepemimpinan perempuan adalah suatu bentuk keterlibatan perempuan dalam memimpin secara mental dan emosional dalam suatu kelompok yang mendorongnya untuk memberikan sumbangan baik dalam bentuk tenaga, fikiran maupun materiil guna tercapainya suatu tujuan tertentu yang akan dicapai. Hal ini sangat ditentukan oleh indikatorindikator seperti :

1. Komunikasi dengan masyarakat dalam pelaksanaan program

2. Loyalitas dalam pelaksanaan tugas

3. Pengambilan keputusan

4. Motivasi kepada masyarakat Keempat indikator tersebut gunakan untuk melihat kepemimpinan peremuan di Desa Lauran yang dapat dijelaskan sebagai berikut :

1. Untuk pernyataan pertama mengenai komunikasi, dari 95 responden ternyata terdapat 6 orang $(6,3 \%)$ menjawab sangat setuju, dan 69 orang $(72,6 \%)$ 
menjawab setuju, serta20orang $(21,1 \%)$ menjawab ragu-ragu.

2. Untuk pernyataankedua mengenai Loyalitas, dari 95 responden ternyata yang menjawab sangat setuju 31 orang $(32,6 \%)$ dan yang menjawab setuju 55 orang $(57,9 \%), \quad$ sedangkan yang menjawab ragu-ragu sebanyak 9 orang $(9,5 \%)$.

3. Untuk pernyataan ketiga mengenai pengambilan keputusan,dari 95 responden ternyata yang menjawab sangat setuju sebanyak 14 orang $(14,74 \%)$, dan yang menjawab setuju sebanyak 48 orang $(50,53 \%)$ sedangkan yang menjawab raguragu sebanyak 19 orang (20\%) serta yang menjawab tidak setuju sebanyak 14 orang $(14,73 \%)$.

4. Untuk pernyataankeempat mengenai motivasi, dari 95 responden ternyata yang menjawabsetuju sebanyak 15 orang $(15,8 \%)$, dan yang menjawab raguragu sebanyak 49 orang $(51,6 \%)$ sedangkan yang menjawab tidak setuju sebanyak 31orang $(32,6 \%)$.

Dari ke empat indicator di atas pada variable terikat yaitu kepemimpinan perempuan, yang perlu untuk perhatikan dan dilakukan yaitu indicator pengambilan keputusan, kerena dalam pengambilan suatukeputusan diperlukan keputusan yang bijaksana dan dapat memberikan kesejahteraan kepada masyarakat setempat.

\section{Persepsi Masyarakat Terhadap \\ Kepemimpinan Perempuan}

Persepsi masyarakat terhadap kepemimpinan perempuan merusapak sebuah proses analisa dan penilain serta evaluasi terhadap manajemen kepemimpinan perumpuan di Desa Lauran. Untuk mengetahui pengaruh antara Persepsi Masyarakat dengan Kepemimpinan Perempuan, dianalisis dengan menggunakan rumus Korelasi Pearson Produk, dimana langka pertama yang dilakukan adalan membuat sebuah tabel penolong untuk perhitungan korelasi, dimana yang memuat total keseluruhan jawaban responden atas variabel $\mathrm{X}$ (Persepsi Masyarakat) dan variabel Y (Kepemimpinan Perempuan) dimana :

$$
\begin{aligned}
\sum \mathrm{X} & =1395 \\
\sum \mathrm{Y} & =1384 \\
\sum \mathrm{X}^{2} & =20727 \\
\sum \mathrm{Y}^{2} & =20386 \\
\sum \mathrm{XY} & =20443 \\
\mathrm{n} & =95
\end{aligned}
$$

Untuk mengetahui hubungan atau pengaruh kedua variabel, maka berdasarkan nilai-nilai dalam tabel penolong diatas tersebut kemudian analisis dengan mengunakan rumus korelasi produck moment, diperoleh nilai Koefisien Korelasi (r) sebesar 0,50 yang 
jika dikonsultasiskan pada tabel interval $r$ berada pada posisi $0,40-0,599$ dengan kategori hubungan yang cukup kuat. Dengan demikian antara variabel $\mathrm{X}$ (Persepsi Masyarakat) dengan variabel Y (Kepemimpinan Perempuan) memiliki hubungan yang cukup kuat.

Sedangkan untuk mengetahui besar kecilnya kontribusi variabel $\mathrm{X}$ (Persepsi Masyarakat) dengan variabel Y (Kepemimpinan Perempuan), digunakan rumus koefisien determinasi. Dengan rumus sebagai berikut: $K D=r^{2} x$ $100 \%$, maka diperoleh nilai $\mathrm{KD}=25 \%$. Hal ini menunjukan bahwa variabel $X$ (Persepsi Masyarakat) memberikan kontribusi sebesar $25 \%$ terhadap variabel Y (Kepemimpinan Perempuan) sedangkan sisanya $75 \%$ ditentukan oleh faktor lain yang tidak sempat diteliti.

Selanjutnya nilai korelasi yang telah didapat kemudian dianalisis untuk membuktikan dan menganalisa tingkat signifikansi hipotesa, maka digunakan uji signifikan dengan formula uji $t$ ( $t-$ hitung) pada taraf signifikan $5 \%(0,05)$ uji dua pihak dengan $\mathrm{dk}=\mathrm{n}-2$ (952=93), dari hasil perhitungan ternyata diperoleh nilai t-hitung sebesar 5,542 lebih besar dari nilai t-tabel 1,980.

Hal ini menunjukan bahwa hipotesa $\mathrm{H}_{\mathrm{a}}$ diterima sedangkan hipotesa $\mathrm{H}_{0}$ ditolak. Dengan demikian hipotesa yang

diajukan

terbukti/teruji

kebenarannya yaitu ada pengaruh antara Persepsi Masyarakat terhadap Kepemimpinan Perempuan Di Desa Lauran Kecamatan Tanimbar Selatan Kabupaten Maluku Tenggara Barat.

\section{KESIMPULAN DAN SARAN}

\section{Kesimpulan}

Berdasarkan hasil pembahasan pada bab-bab terdahulu dan hasil analisa yang telah diuraikan untuk mengetahui pengaruh antara variabel $\mathrm{X}$ (Persepsi Masyarakat) terhadap variabel Y (Kepemimpinan Perempuan) maka dapatlah ditarik kesimpulan sebagai berikut :

Untuk perhitungan korelasidiperoleh nilai $\mathrm{r}=0,52$ yang berada pada taraf interfal $0,40-0,599$ dengan kategori hubungan yang cukup kuat. Dengan demikian antara variabel $X$ (Persepsi Masyarakat) dengan variabel $\mathrm{Y}$ (Kepemimpinan Perempuan) di Desa Lauran KecamatanTanimbar Selatan Kabupaten Maluku Tenggara Barat memiliki hubungan yang cukup kuat. Sedangkan koefisien determinasi yang telah diperoleh menunjukan bahwa variabel $\mathrm{X} \quad$ (Persepsi Masyarakat) memberikan kontribusi sebesar 25\% terhadap variabel $\mathrm{Y}$ (Kepemimpinan Perempuan) sedangkan sisanya $75 \%$ ditentukan oleh faktor lain yang tidak 
sempat diteliti.

Selanjutnya untuk uji signifikansi dengan menggunakan uji $\mathrm{t}(\mathrm{t}$ - hitung) pada taraf signifikan $5 \%(0,05)$ uji dua pihak dengan $\mathrm{dk}=\mathrm{n}-2 \quad(95-2=93)$, diperoleh nilai t-hitung sebesar 5,542 nilai t-hitung ini kemudian di konsultasikan dengan nilai t-tabel pada taraf signifikan $5 \%(0,05) \mathrm{dk}=93$ yaitu 1,980 .

Dengan demikian nilai t-hitung $\geq$ dari nilai t- tabel $(5,542 \geq 1,980)$. Sehingga dapat dikatakan bahwa hipotesa penelitian terbukti/teruji kebenarannya yakni ada pengaruh yang signifikan antara Persepsi Masyarakat terhadap Kepemimpinan Perempuan Di Desa Lauran Kecamatan Tanimbar Selatan Kabupaten Maluku Tenggara Barat.

\section{Saran}

Berdasarkan kesimpulan yang telah dikemukakan di atas, maka dapat disarankan beberapa hal sebagai berikut :

1. Kepala Desa Perempuan harus bisa memberikan pemahaman yang lebih kepada masyarakat Desa Lauran dalam menjalankan berbagai program desa.

2. Dalam menjalankan program desa, Kepala Desa Perempuan tidak boleh hanya melibatkan orang-orang tertentu saja, sehingga masyarakat yang lain juga bisa ikut ambil bagian dalam menjalankan program desa.

3. Kepala Desa Lauran perlu melakukan pengarahan kepada masyarakat desa, sehingga semua program desa dapat dijalankan sesuai dengan yang direncanakan.

4. Dalam pengambilan keputusan sebaiknya kepala desa tidak hanya mengambil keputusan secara sepihak, namun sebaiknya keputusan yang diambil perlu dipertimbangkan demi kepentingan bersama bukan hanya kepentingan sepihak. 


\section{DAFTAR PUSTAKA}

Abdul Syani (2007:30). Sosiologi Skematika, Teori dan Terapan . PT. Bumi Aksara Jakarta

Auguste Comte dalam Abdul Syani (2007:31). Pengertian Masyarakat. http://digilib.unila.ac.id/920/3/Bab\%202.pdf

Arikunto, Suharsimi. 2010. Prosedur Penelitian Suatu Pendekatan Praktik. Jakarta: Rineka Cipta.

Astuti, Tri Marhaeni P. 2011. Konstruksi Gender dalam Realitas Sosial. Semarang: Unnes Press.

Dzuhayatin, Sri Ruhaini. 2011. Kepemimpinan Perempuan Perempuan.

Di

Indonesia (Tantangan dan Peluang). http:

//perempuanpolitik. com/kepemimpinan-perempuan-

diindonesiatantangan-dan-peluang/.

Ciptaningsih Utaryo. 1992. Permasalahan Perempuan Di Negara Berkembang. Yogyakarta : Tiara Wacana Yogya.

Kartini, Kartono. 1990. Psikologi Perkembangan Anak. Bandung. CV. Mandiri. . 2005. Pemimpin dan Kepemimpinan. Jakarta : PT. Raja Grafindo Persada.

. 2013. Pemimpin dan Kepemimpinan, Apakah Kepemimpinan Abnormal itu?. Jakarta: PT Raja Grafindo Persada.

Luthfi, Asma dan Atika Wijaya. 2011. Persepsi Masyarakat Sekarang Tentang Konservasi Lingkungan. Jurnal Komunitas, Vol. 3 No. 1: 29-39.

Miftah, Toha. 2003. Perilaku Organisasi, Konsep Dasar dan Aplikasinya. Jakarta: PT. Raja Grafindo Persada

Purwodarminto (1990:759). Teori Dan Pengertian Perubahan Sosial.

http://googleweblight.com/?lite_url=http://belajarpsikologi.com/pengerti a $\underline{n}$-perubahan-sosial/\&Ic=id-

ID\&s=1\&m=936\&host=www.google.co.id\&ts=1505617624\&sig=ANT $\underline{\mathrm{Y}}$ L2tPvgCWI8vjy4_oAXuoD4IAsHBRw

Pieter, H.Z. \& Lubis, N.L. 2010 Pengantar Psikologi Dalam Keperawatan. Jakarta: Kencana

Sugiyono. 2010. Metode Penelitian Pendidikan Pendekatan Kuantitatif, 
Kualitatif dan $R \& D$. Alfabeta: Bandung. (2009 :3) : Metode Penelitian. S_PEA_0800999_CHAPTER3.pdf (2009:11) Pendidikan Matematika oleh Grace Evangelia

Supartiningsih. 2003. Peran Ganda Perempuan, Sebuah Analisis Filosofis Kritis. Jurnal Filsafat, Jilid 33. Nomor 1: 42-54.

Situmorang, Nina Zulida. 2011. Gaya Kepemimpinan Perempuan. Jurnal Proceeding PESAT. Vol 4. ISSN 1858-2559. 